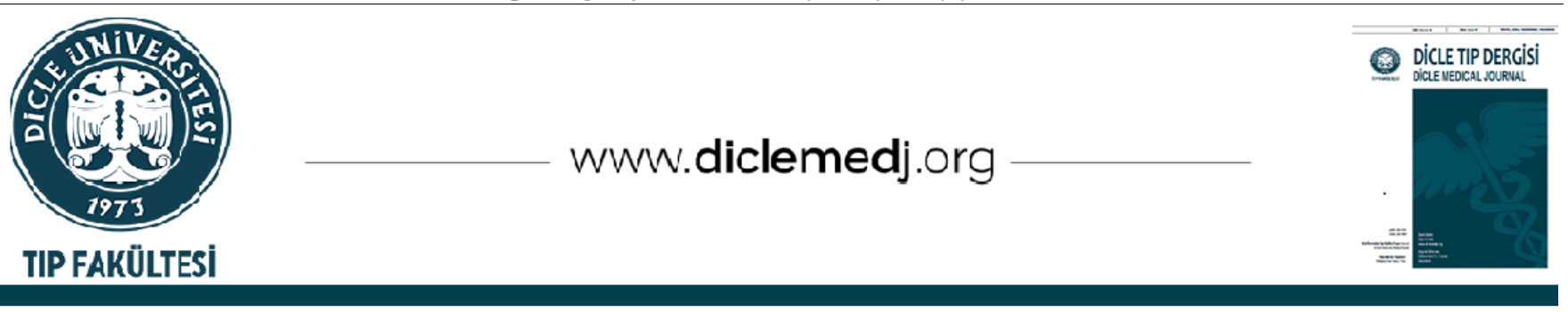

\title{
Deneysel Diyabetik Sıçan Modelinde Zamana Bağlı Gelişen Kemik Dokusundaki Değișikliklerin İncelenmesi
}

\author{
Dilek Aygün Keşim ${ }^{i}$, Mustafa Kelle ${ }^{D}{ }^{2}$, Hüda Diken ${ }^{D}$, Hacer Kayhan Kaya ${ }^{2}$, Engin Deveci ${ }^{3}$, \\ Figen Koç Direk ${ }^{i}{ }_{4}$, Cihan Gül ${ }^{i}{ }_{5}$ \\ 1 Dicle Üniversitesi Tıp Fakültesi Fizik Tedavi Ve Rehabilitasyon Anabilim Dalı Diyarbakır, Türkiye
}

2 Dicle Üniversitesi Tıp Fakültesi Fizyoloji Anabilim Dalı Diyarbakır, Türkiye

3 Dicle Üniversitesi Tıp Fakültesi Histoloji Anabilim Dalı Diyarbakır, Türkiye

4 Dicle Üniversitesi Tıp Fakültesi Anatomi Anabilim Dalı Diyarbakır Türkiye

5 Batman Üniversitesi Sağlık Meslek Yüksekokulu Batman Türkiye

Geliş: 12.02.2021; Revizyon: 30.04.2021; Kabul Tarihi: 03.05.2021

Öz

Amaç: Streptozotocin (STZ) ile oluşturulan diyabetin, kemik metabolizması üzerine etkisinin araștırılması amaçlanmıștır.

Yöntemler: Çalışmada 28 adet 350-400 gr ağırlı̆̆ında Wistar albino türü erkek sıçanlar kullanıldı. Her bir grupta 7 adet sıçan kullanıldı. Sıçanlar 2 haftalık kontrol ve diyabet (streptozotocin), 8 haftalık kontrol ve diyabet olmak üzere toplam 4 gruba ayrıldı. Diyabetli gruplara tek seferlik streptozotocin $45 \mathrm{mg} / \mathrm{kg}$ doz karın boşluğuna enjekte edildi. Sıçanlar belirlenen haftalarda ketamin anestezisi altında kardiyak ponksiyonla feda edilerek, kan ve sağ tibia örnekleri alındı. Tibiaları hemotoksilen boya ile boyanıp, histopatolojik görüntüleri elde edildi. Tibia uzunlukları ölçülüp kaydedildi. Kan serum örneklerinden vitamin D, kalsiyum, magnezyum, fosfat ve alkalen fosfataz değerleri ölçüldü.

Bulgular: Hem iki hem de sekiz haftalık diyabetik grupların kendi kontrollerine kıyasla vücut ağırlı̆ında anlamlı azalma göründü (p<0,01). Açlık kan şekeri ortalaması 2. Haftadaki diyabetli grupta $385 \mathrm{mg} / \mathrm{dl}$ iken 8. Haftadaki diyabetli grupta $496 \mathrm{mg} / \mathrm{dl}$ olarak ölçüldü. Histopatolojik incelemelerde ilk 2 hafta olan kontrol ve diyabetli gruplar arasında fark görünmezken, 8 haftalık diyabetli gruptaki sıçanların kemiklerinde osteosit hücrelerde dejenerasyon bulundu. Tibia uzunluğunda 2.haftadaki gruplar arasında anlamlı fark bulunmazken ( $p>0,05$ ), 8. Haftadaki diyabetli grupta kontrolüne klyasla anlamlı azalma bulundu( $(\mathrm{p}<0,01)$. Biyokimyasal serum değerlerinde 2 haftalık diyabetli grupta kendi kontrol grubuna kıyasla Ca ve ALP düzeylerinde anlamlı değişiklikler meydana geldi( $\mathrm{p}<0,01) .8$ haftalık diyabetli olan grupta kontrole kıyasla serum $\operatorname{Mg}(p<0,05)$, Ca, P ve ALP değerlerinde $(p<0,01)$ diyabet aleyhine anlamlı farklılıklar bulundu.

Sonuç: STZ ile oluşturulan diyabetik modellerde erken dönemde kemikte herhangi bir patolojiye rastlanmazken, uzun vadede osteosit hücrelerde dejenerasyon, kemik oluşumunda azalma ve serum biyokimyasal değerlerinde bozukluklar ortaya çlkmaktadır. Ayrıca hiperglisemiye bağlı gelişen D vitamini ve Ca metabolizmasındaki bozukluklar düşük kemik kütlesine yol açabilir ve kırık olasılığını artırabilir. Diyabetik hastalarda kemik sağlığı ihmal edilmemeli ve erken dönemde önlemler alınmalıdır.

Anahtar kelimeler: Diabetes mellitus, kemik, rat, streptozotocin, tibia, osteosit

DOI: 10.5798/dicletip.944399

Yazışma Adresi / Correspondence:Dilek Aygün Keșim; Dicle Üniversitesi Tıp Fakültesi Fizik Tedavi Ve Rehabilitasyon Anabilim Dalı Diyarbakır, Türkiye e-mail: dilekaygunkesim@gmail.com 


\title{
Investigation of Changes in Bone Tissue Developing with Time in Experimental Diabetic Rat Model
}

\begin{abstract}
Objective: It was aimed to investigate the effect of diabetes induced by streptozotocin (STZ) on the bone metabolism.

Methods: In the study, 28 male Wistar albino rats weighing 350-400 g were used. 7 rats were used in each group. The rats were divided into 4 groups: 2-week control and diabetes (streptozotocin), 8-week control and diabetes. The diabetic groups were injected with a single dose of streptozotocin $45 \mathrm{mg} / \mathrm{kg}$ into the abdominal cavity. Blood and right tibia samples were taken by sacrificing rats with cardiac puncture under ketamine anesthesia in the specified weeks. Histopathological images were obtained by staining the tibia with hematoxylindye. Tibia lengths were measured and recorded. Vitamin D, calcium, magnesium, phosphate and alkaline phosphatase values were measured from blood serum samples.
\end{abstract}

Results: A significant decrease was observed in body weight of both two week and eight week diabetic groups compared to their own control(p <0.01). While fasting blood glucose was $385 \mathrm{ml} / \mathrm{dl}$ in the diabetic group on the 2nd week, it was measured as $496 \mathrm{mg} / \mathrm{dl}$ in the diabetic group on the 8th week. In histopathological examinations, there was no difference between the control and diabetic groups in the first 2 weeks, while degeneration was found in osteocyte cells in the bones of 8-week old diabetic rats. While there was no significant difference in tibia length between the groups in the 2 nd week $(p>0,01)$, a significant decrease was found in the diabetic group at the 8 th week compared to the control $(\mathrm{p}<0,01)$. In biochemical serum values in 2 -week diabetic group, compared to its own control, significant changes occurred in Ca and ALP values $(p<0,01)$. Significant differences were found against diabetes in the 8 -week diabetic group in terms of serum $\mathrm{Mg}(\mathrm{p}<0,05), \mathrm{Ca}, \mathrm{P}$ and ALP values $(\mathrm{p}<0,01)$ compared to the control.

Conclusion: While in diabetic models created with STZ, no pathology is seen in bone in the early period, degeneration in osteocyte cells, decrease in bone formation and defects in serum biochemical markers occur in the long term. In addition, defects in vitamin D and Ca metabolism due to hyperglycemia may lead to low bone mass and increase the possibility of fracture. Bone health should not be neglected in diabetic patients and early precautions should be taken.

Keywords: diabetes mellitus, bone, rat, streptozotocin, tibia, osteocyte.

\section{GíRiş}

Diabetes mellitus (DM), tam veya kısmi insülin yokluğuyla ortaya çlkan bir metabolik hastalıktır $^{1}$. Tip 1 diabetes mellitus (T1DM), pankreas tarafından insülin üretiminin olmamasından kaynaklanır ve günlük insülin uygulanmasını gerektirir. Etyolojisinde otoimmün pankreas beta $(\beta)$ hücrelerinin yok edilmesi yer alır. Tip 2 diabetes mellitus (T2DM), insülin direncinin üstesinden gelmek için yeterli miktarda insülin üretememe ile birlikte insülin direnci olarak anılan, insülini verimli bir şekilde kullanamama ile karakterizedir. Diabetes mellitus genellikle kalbi, kan damarlarını, gözleri, böbrekleri ve sinirleri etkileyen ciddi komplikasyonlara yol açar. Diyabetin kemik sağlığını olumsuz etkilediği de giderek artan bir şekilde kabul edilmektedir ${ }^{2,3}$.

Diabetes mellitus, kırık riskini artıran ve kemik oluşumunu engelleyen ve kırık iyileşmesini bozan metabolik bir hastalıktır.
Hem T1DM hem de T2DM, artmış osteoporoz ve kırık riski ile ilişkilidir. T1DM'de kemik mineral yoğunluğu azalırken, T2DM'li hastaların kemik yoğunluğunun normal veya biraz daha yüksek olması, kemik kalitesinin bozulduğunu düşündürür. T1DM'nin iskelet üzerindeki zararlı etkileri, muhtemelen insülin ve diğer pankreas hormonlarının osteo-anabolik etkilerinin olmaması nedeniyle T2DM'den daha şiddetlidir4. T1DM ve T2DM'de düşük kemik kalitesi, hiperglisemi, ileri glikozilasyon son ürünlerinin (AGE'ler) birikimi, reaktif oksijen türleri (ROS) üretimi ve iltihaplanma, serum osteokalsin ve paratiroid hormon seviyelerinde azalma dahil olmak üzere kemiği etkileyen birkaç ortak özelliğe sahiptir. Bu faktörler hem osteoblastları hem de osteoklastları etkiler, osteoklastların artmasına ve osteoblast sayısının azalmasına yol açar ${ }^{3}$. 
Streptozotocin (STZ) deney hayvanlarında deneysel diyabet oluşturmak için kullanılan diyabetojenik bir bileșiktir. STZ'nin yapısında glukoz bulunduğu için pankreasta bulunan beta hücrelerine GLUT-2 yoluyla alınır ve DNA alkilasyonuna neden olur. DNA tamiri gerçekleşir ve tamir sırasında NAD kullanılarak hücre içindeki NAD depolarını boşaltır ve ATP içeriğini azaltır. Hücrenin enerji depolarındaki yokluk $\beta$ hücrelerinin nekroza uğramasına sebebiyet verir. STZ uygulaması sonrasinda pankreasta serbest radikallerde artışa ve beta hücrelerindeki nekroz insülin üretme kabiliyetinin bozulmasına yol açarak deneysel diyabeti ortaya çıkarır ${ }^{5}$.

$\mathrm{Bu}$ çalışmada deneysel diyabetik sıçanlarda değişen haftalarda kemik dokusunda ve serum değerlerinde görülen değişiklikleri incelemek amaçlanmıştır.

\section{YÖNTEMLER}

\section{Deney Hayvanları}

Araştırmamızın canlı materyali olan 28 adet Wistar albino ırkı erkek sıçan Dicle Üniversitesi Deney Hayvanları Ünitesinden temin edildi. 810 haftalık, 360-400 gr ağırlığındaki hayvanlar, deneyin sonuna kadar $22 \pm 2{ }^{\circ} \mathrm{C}$ oda sıcaklığında 12 saat aydınlık/ 12 saat karanlık ışık periyodunda barındırıldı ve normal diyet ve musluk suyu ile herhangi bir kisitlama yapılmaksızın beslendi. Çalışmaya başlanmadan önce hayvanların kan glukoz değerlerine bakıldı. Yapılan çalışmada parametrelere olumsuz etki edecek faktörlerin en aza indirilmesi için gerekli bütün önlemler alındıktan sonra uygulamaya geçildi. Bu çalışma için etik kurul onayı Dicle Üniversitesi Hayvan Deneyleri Yerel Etik Kurulu'ndan alınmıștır(01/10/2019-106141).

Grupların her birinde 7 adet sıçan bulunacak şekilde 4 gruba ayrıldı.

Grup 1: Kontrol grubu: Bu gruba herhangi bir şey uygulanmadı 2 hafta sonrasında feda edildi.
Grup 2: DM2: STZ ile diyabet olușturulduktan 2 hafta sonra feda edildi.

Grup 3:Kontrol grubu: Bu gruba herhangi bir şey uygulanmadı 8 hafta sonra feda edildi.

Grup 4: DM8: STZ ile diyabet oluşturulduktan 8 hafta sonra feda edildi.

\section{STZ ile Oluşturulan Diyabet Modeli}

Diyabet oluşturmak için sıçanların karın boşluğuna tek doz nikotinamid $(110 \mathrm{mg} / \mathrm{kg})$ uygulandiktan 30 dakika sonra sitrat tamponunda hazırlanmış olan STZ çözeltisinden karın boşluğuna $45 \mathrm{mg} / \mathrm{kg}$ tek doz olarak uygulandı ve 72 saat sonra kuyruk veninden alınan kan örneğinde açlık kan şekeri glukometre (On callplus) ile ölçüldü. Açlık kan glikoz düzeyleri $14 \mathrm{mmol} / \mathrm{dl}=250 \mathrm{mg} / \mathrm{dl}$ ve üzerinde olanlar diyabetik gruplara dahil edildi. Sağlıklı deney grubunu oluşturan diğer sıçanlarda diyabet oluşturulmadı.

2 ve 8 haftalık deney periyodunun sonunda sıçanlar, 12 saatlik açlığı takiben ketamin anestezisi altında kardiyak ponksiyonla feda edilerek kan ve kemik örnekleri alındı. Kan örnekleri, kardiyak delme ile toplandı ve hemen 3500 rpm'de 20 dakika süreyle santrifüjlendi. Serum örnekleri biyokimyasal analize kadar -70 ${ }^{\circ}$ C'de saklandı. Deney boyunca vücut ağırlığı ve besin alımı haftalık olarak kaydedildi. Kan örneklerinde kalsiyum (Ca), magnezyum (Mg), fosfor (P), Alkalenfosfataz (ALP), 1,25 dihidroksi vitamin D değerleri ölçüldü. Kemik örnekleri sağ tibiadan alındı.

\section{Kemik Doku Takibi}

Kemikler ilk olarak \%10'luk nötral buffered formalin solüsyonuna tutuldu. Daha sonra kemik dekalsifikasyonu için \%10'luk formik asit solüsyonunda 2 ay süre ile bekletildi. Asit solüsyonu haftalık olarak değiştirildi. Yumuşayan kemik dokularına rutin parafin doku protokolü uygulandı. Kemik dokusu içeren bloklardan mikrotom (katalog no: Leica RM2265, Wetzlar, Germany) yardımıyla 4-6 $\mu \mathrm{m}$ 
kalınlığında kesitler alınarak HematoksilenEozin boyaması yapıldı.

\section{Hematoksilen-Eozin Boyama}

Parafin bloklardan alınan kas, kalp ve kemik doku kesitleri $37^{\circ} \mathrm{C}$ 'ye ayarlanmış benmariye alındı. Lam üzerinde fazla parafini eritmek için kesitler $58-62^{\circ} \mathrm{C}$ etüvde 6 saat boyunca bekletildi. Kesitler 3x15 dakika ksilendedeparafinize edildi. Kesitler azalan alkol serilerinden (\%100, \%96, \%90, \%70, \%50 etil alkol) 10'ar dakika geçirildi ve distile suya getirilerek 5 dakika bekletildi. Harris Hematoksilen boyasında 8 dakika bekletildikten sonra kesitler akan su altında 5 dakika yıkandı. Kesitler durulandı ve alkolik eozin boyasında 6 dakika bekletildi. Kesitler artan alkol serilerine (\%80, \%90, \%96 etil alkol serilerinden geçirilerek) hızlıca daldırıldı ve absolü alkolde 2 dakika bekletildi. Son olarak kesitler 3x15 dakika ksilende bekletildi ve doku üzerine Entellan damlatılarak lamelle kapatıldı.
Dokular daha sonra Leica Zeiss Imager A2 $1 s ̧ ı k$ mikroskobu altında incelendi.

\section{İstatistiksel Analiz}

Elde edilen sonuçlar IBM SPSS( 20 ABD yazılımı) kullanılarak istatistiksel yöntemlerle değerlendirildi. Gruplar arası fark student-t testi ile değerlendirildi. Değerler ortalama \pm standart hata olarak hesaplandl. $\mathrm{P}<0,05$ değeri anlamlı kabul edildi.

\section{BULGULAR}

Kontrol grubu sıçanların tibia kemiğinin normal histolojik görünümde oldukları görüldü(Şekil 1A-şekil 2A). DM grubu sıçanların ise 2 haftalık olanlarda herhangi bir patolojiye rastlanmadi (Şekil 1B). 8 haftalık diyabetli olanlarda patolojiye rastlandı. Özellikle kemiğin matriks yoğunluğunda belirgin azalma izlenirken, havers kanallarında düzensiz yerleşim ve aşırı dilatasyon izlendi. Osteosit hücrelerinde hipertrofi ve dejenerasyonlar gözlendi(Şekil 2B).

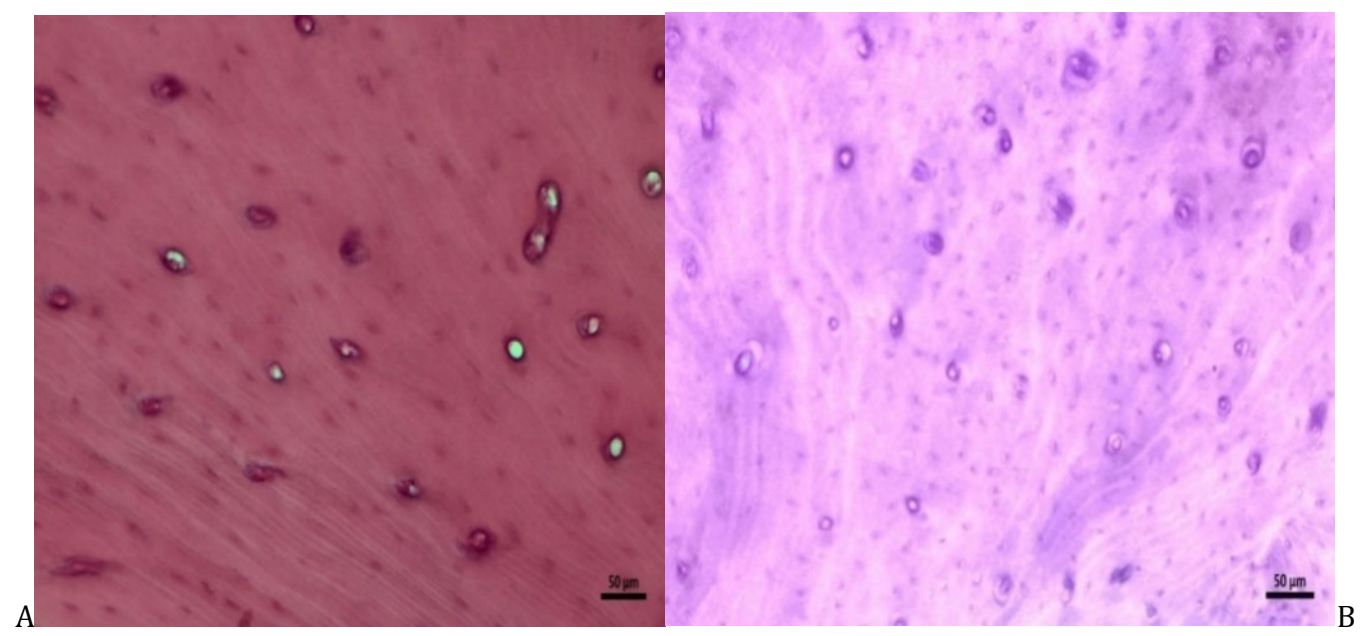

Şekil 1: Kontrol 2 Haftalık (A): Normal histolojik görünüm, Diyabetik 2 Haftalık (B): Kompakt kemik bölgesinde osteosit hücrelerinin düzenli olduğu, havers kanal sisteminin oval şeklinde birbirlerine paralel şeklinde izlendiği ve volkman kanallarının iki havers kanalı arasında düzenli yerleștiği gözlendi. Hematoksilen-Eozin boyama Bar: $50 \mu \mathrm{m}$ 

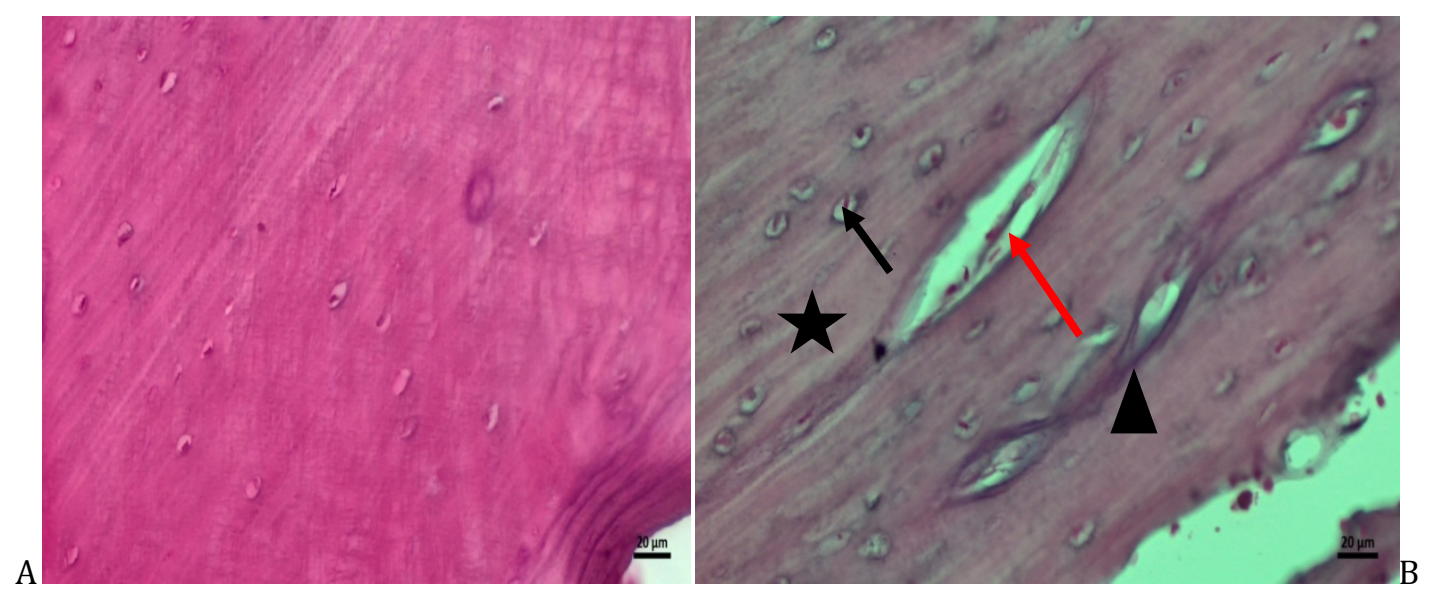

Şekil 2: Kontrol 8 Haftalık (A): Normal histolojik görünüm. Diyabetik 8 Haftalık (B): Kemik matriks yoğunluğunda belirgin bir azalma izlenirken (yıldız), özellikle havers kanallarında düzensiz yerleşim (üçgen) ve aşırı dilatasyon (kırmızı ok) izlendi. Osteosit hücrelerinde hipertrofi (siyah ok) ve havers kanallarının iç tarafında küçük dejenerasyonlar gözlendi. Hematoksilen-Eozin boyama, Bar: $20 \mu \mathrm{m}$

Tablo I: 2 haftalık grupların açlık kan şekeri, ağırlıkları, tibia uzunlukları ve serum biyokimyasal değerleri

\begin{tabular}{|l|l|l|l|}
\hline & $\begin{array}{l}2 \\
\text { Kontrol }\end{array}$ & Haftalık & 2 Haftalık \\
Dan & $120,71 \pm 10,06$ & $385,57 \pm 78,30$ & $0,00^{* *}$ \\
\hline $\begin{array}{l}\text { Açlık değeri } \\
\text { șekeri(mg/dl) }\end{array}$ & $\begin{array}{l}\text { Diyabet } \\
\text { (gr) }\end{array}$ & $397 \pm 24$ & 0,51 \\
\hline Son ağırlangıç ağırlığl (gr) & $408 \pm 34$ & $331 \pm 28$ & $0,00^{* *}$ \\
\hline $\begin{array}{l}\text { Tibia } \\
\text { uzunluğu(mm) }\end{array}$ & $15,42 \pm 0,48$ & $15,28 \pm 0,28$ & 0,61 \\
\hline D vitamini(ng/ml) & $28,99 \pm 1,86$ & $28,62 \pm 1,67$ & 0,70 \\
\hline Ca (mg/dl) & $9,81 \pm 0,97$ & $9,51 \pm 0,16$ & $0,00^{* *}$ \\
\hline Mg (mg/dl) & $1,87 \pm 0,21$ & $1,90 \pm 0,19$ & 0,79 \\
\hline P(mg/dl) & $7,85 \pm 1,50$ & $7,58 \pm 0,61$ & 0,38 \\
\hline Alp(IU/L) & $90,45 \pm 3,95$ & $95,28 \pm 3,25$ & $0,02^{*}$ \\
\hline$* P$ değeri<0,05**P<0,01 & & \\
\hline
\end{tabular}

Deney hayvanlarının başlangıç ağırlıkları arasında anlamlı bir fark yoktu $(\mathrm{p}>0,05)$. Deney sonunda diyabetli olan gruplarda son ağırlık anlamlı oranda düşüktü $(\mathrm{p}<0,01)$. Açlık kan şekeri ortalaması 2 haftalık diyabetli grupta 385 $\mathrm{mg} / \mathrm{dl}$ iken 8 haftalık diyabetli grupta $496 \mathrm{mg} / \mathrm{dl}$ idi. Tibia uzunluğu 2 haftalık kontrol ve diyabetli gruplar arasında anlamlı fark bulunmadı( $\mathrm{p}>0,01)$.

Serum biyokimyasal parametrelerinden D vitamini iki haftalık gruplar arasında anlamlı bir farklılık bulunmadı( $p>0,05)$. Serum kalsiyum değeri iki haftalık diyabetli olan grupta kontrole göre diyabette anlamlı olarak daha düşüktü $(p<0,01)$. Serum Magnezyum ve fosfat değerlerinde iki haftalık gruplar arasinda anlamlı bir fark bulunmazken ( $p>0,05)$; alkalen fosfataz düzeyleri iki haftalık diyabetli grupta kontrole kıyasla anlamlı olarak daha yüksekti $(\mathrm{p}<0,01)$.

Tablo II: 8 haftalık grupların açlık kan şekeri, ağırlıkları, tibia uzunlukları ve serum biyokimyasal değerleri

\begin{tabular}{|l|l|l|l|}
\hline & 8 Haftalık Kontrol & 8 Haftalık Diyabet & P değeri \\
\hline Açlık kan șekeri(mg/dl) & $106,14 \pm 3,93$ & $496,28 \pm 55,22$ & $0,00^{* *}$ \\
\hline Başlangıç ağırlığı (gr) & $433 \pm 24$ & $401 \pm 42$ & 0,10 \\
\hline Son ağırlık (gr) & $442 \pm 30$ & $281 \pm 36$ & $0,00^{* *}$ \\
\hline Tibia uzunluğu(mm) & $17,14 \pm 0,69$ & $16,13 \pm 0,78$ & $0,00^{* *}$ \\
\hline D vitamini(ng/ml) & $27,35 \pm 3,47$ & $25,41 \pm 2,98$ & 0,28 \\
\hline Ca (mg/dl) & $9,80 \pm 0,07$ & $8,85 \pm 0,71$ & $0,00^{* *}$ \\
\hline Mg (mg/dl) & $1,82 \pm 0,17$ & $1,64 \pm 0,12$ & $0,04^{*}$ \\
\hline P(mg/dl) & $7,70 \pm 1,50$ & $5,51 \pm 0,31$ & $0,00^{* *}$ \\
\hline Alp(IU/L) & $93,19 \pm 1,74$ & $140,85 \pm 5,17$ & $0,00^{* *}$ \\
\hline
\end{tabular}

${ }^{*}$ P değeri $<0,05^{* *} P<0,01$ 
Tibia uzunluğu 8 haftalık diyabetli grupta kendi kontrol grubuna kıyasla anlamlı oranda düşük bulundu $(\mathrm{p}<0,01)$.

Sekiz haftalık grupların D vitamini düzeyi diyabetli olanlarda kontrole göre düşüktü ancak anlamlı değildi $(p>0,05)$. Kalsiyum düzeyleri sekiz haftalık gruplar arasında diyabette anlamlı olarak daha düşüktü $(\mathrm{p}<0,01)$. Sekiz haftalık gruplar arasında magnezyum ve fosfat yine diyabetli olan grupta anlamlı olarak daha düşüktü $(\mathrm{p}<0,05)$. Alkalen fosfat düzeyleri diyabette kontrole kıyasla anlamlı olarak yüksek bulundu $(\mathrm{p}<0,01)$.

\section{TARTIŞMA}

Hedeflerimiz, diyabetin sıçan iskeleti üzerindeki etkilerini ölçmek, kemik boyutu ve serum biyokimyasal değerlerinin zamansal değișiklikleri hakkında yeni veriler sağlayarak önceki çalışmalarla karşılaştırmaktı. Yaş uyumlu kontrollere kıyasla diyabetik sıçan kemiğinde önemli patolojilere rastladık. Özellikle ilk 2 haftalık olan gruplarda kayda değer patoloji görünmezken 8 haftalık diyabetli sıçanlarda kemiğin yapısında bozulmalar; osteosit hücrelerde dejenerasyon, havers kanallarında düzensiz yerleşim ve dejenerasyon görülmüştür.

Önceki çalışmalar, streptozotocin ile indüklenen diyabetik sıçanlarda kemik boyutunda ve kemik mineral yoğunluğunda eksiklikleri belgelemiştir. Bununla birlikte ne hayvan ne de insan çalışmaları, diyabetik osteopeninin kemik kaybından mı yoksa büyüme sırasında azalmış kemik oluşumundan mı kaynaklandığı sorusunu tam olarak açiklayamamıştır. İnsanlarda tip 1 diyabetin başlama yaşı tipik olarak iskelet olgunluğundan önce olduğundan, streptozotocin modeli, büyüyen sıçanlarda kullanılarak uygulandı. Aynı yaşa denk gelmesi için farklı haftalarda kontrol grubu eklendi. Diyabetik sıçanlardaki osteopeninin trabeküler kemik kaybından kaynaklandığı bazı çalışmalarda açıklanmıştır. Ayrıca aynı çalışma diyabette kortikal kemiklerin büyümesinin durduğunu da göstermiștir6. Bizde bu sebeple tibia uzunluğunu 2 ve 8 haftalarda ölçtüğümüz sonuçlara göre diyabette kontrole klyasla büyümenin azaldığını tespit ettik. Birlikte ele alındığında diyabette osteopeninin büyük ölçüde azalmış kemik oluşumundan ve ardından kemik kaybından kaynaklandığını göstermektedir.

Tip 1 diyabetin kemik mineral yoğunluğunu azalttı̆̆ı diğer çalışmalarca bilinmektedir ${ }^{7}$. Tip1'i taklit eden streptozotocin kaynaklı diyabetik farelerde azalmış kemik büyümesinin eşlik ettiği insülin benzeri büyüme faktörü(IGF1), IGF-1 reseptörleri ve insülin reseptörlerinin ekspresyonunda azalma gösterilmiştir8. Biz kemik mineral yoğunluğu yerine serum alkalin fosfataz düzeylerini ölçtük. Kemik Alkalin fosfataz düzeyi ile kemik mineral yoğunluğu arasında ters orantılı bir korelasyonun olduğu birkaç çalışma ile bildirilmiştir ${ }^{9}$. Alkalin fosfatazın kemik oluşumunun bir belirteci olduğu ve kemik mineral yoğunluğu azaldıkça arttığı bulunmuştur. Bizim sonuçlarımıza göre diyabet ile geçen süre arttıkça serum alkalin fosfatazın arttığı bunun da kemik mineral yoğunluğunda azalmaya denk geldiğini ve diyabet olmayan sağlıklı gruplarda böyle bir azalmanın olmadığını belirledik.

Deneysel ve klinik çalışmaların kapsamlı sonuçları, D vitaminin pankreas beta hücresinin düzgün çalışması, kalsiyum seviyeleri, insülin sekresyonu ve insülin sinyallemesinin potansiyel bir düzenleyicisi olduğunu göstermiștir. Diyabetli hastalar düşük D vitamin seviyesi ile belirlenebilen artmış kırık riskine sahiptir ${ }^{10}$. Çok az çalışma ise tip 1 diyabet ile D vitamin düşüklüğü arasında ilişki bulamamıștır'11. Bizde çalışmamızda 2 haftalık diyabetli ve sağlıklı gruplar arasında fark göremezken 8 haftalık diyabetli grupta kontrole göre bir azalma tespit ettik ancak anlamlı değildi. 2 haftalık diyabet ile 8 haftalık diyabeti karşılaştırılmasında anlamlı bir azalma bulduk. 
Bunun sonucunda diyabette geçen sürenin uzunluğunun D vitamin seviyesini azalttığını düşünmekteyiz.

STZ kaynaklı diyabette Ca emiliminde belirgin bir düşüş, idrarla $\mathrm{Ca}$ atımında 3 kat artış ve hiperfajiden dolayı deney hayvanlarının $\mathrm{Ca}$ alımında artış görülmektedir. Bu koşullar altında diyabetik sıçanlar plazma kalsiyumunu normale yakın tutmak için, iskelet kalsiyumunu kontrole göre çok daha hızlı değiştirirler. Normal hayvanlarda iskelet, plazma kalsiyumunun hem deposu hem de düzenleyicisi olarak hizmet etse de, STZ ile indüklenen diyabette kemikte Ca depolanması yoktur ve iskelet sadece Ca homeostazının düzenleyicisi rolünü oynar' ${ }^{12}$. Bizim çalışmamızda önceki çalışmaları destekler nitelikte olup diyabetik olan her iki grupta da kontrole kıyasla anlamlı olarak serum Ca düzeyi düşük bulundu.

İnsan ve deneysel DM'nin önemli bir özelliği Ca ve Mg'un idrarla atılımının artmasıdır. Plazma Ca konsantrasyonunu korumak için kemikten Ca yer değiştirmesine sebep olur, yani azalmış kemik mineral içeriği hiperkalsiürinin bir sonucudur ${ }^{13}$.

Çalışmamızın serum $\mathrm{Mg}$ ve $\mathrm{P}$ miktarlarında 2 haftalık diyabet ve kontrol grubu arasında anlamlı bir fark tespit etmedik. STZ ile indüklenen diyabetik sıçanlarda, distal tubülde artan $\mathrm{Mg}$ yükü için artan renal $\mathrm{Mg}$ taşıyıcısı telafi edici bir adaptasyon olarak gelişmiștiri ${ }^{14}$. Ancak 8 haftalık diyabetli grubumuzda aynı yaştaki kontrole göre anlamlı oranda düşüş tespit ettik. Buna adaptasyon mekanizmasını aşan oranda magneziürinin sebep olduğunu düşünmekteyiz.

Çalışmamızın bazı sınırlılıkları da vardı. İlk olarak diyabetik süre kayda değer iskelet etkilerini görmek için yeterince uzun olan ama kronik durumu tespit etmeyebilen 8 hafta idi. Daha uzun bir diyabet süresinin daha büyük değişikliklere yol açması muhtemeldir. Ayrıca streptozotocin enjekte edilen hayvanların kontrolsüz hiperglisemi geliştirmesine izin verdik. Bu nedenle bulgularımız daha kötü bir senaryoyu temsil eder ve serum glikoz seviyelerini kontrol eden hastaları kapsamayabilir.

\section{SONUÇ}

Diyabetes mellitusta kemik değişiklikleri durumunun altında yatan patogenez çok faktörlüdür. Ana eksiklikler kemik mineral oranında azalma, kemik osteosit hücre yoğunluğunda dejenerasyon ve azalma, osteoblast aktivitesinde azalma, gelişmiş glikasyon son ürünlerinin birikmesi ve diyabetik kemiğe yol açan oksidatif strestir. Ayrıca hiperglisemiye bağlı gelişen D vitamini ve Ca metabolizmasındaki bozukluklar düşük kemik kütlesine yol açabilir ve kırık olasılığını artırabilir.

Her diyabetik hasta, kırıklar ve osteoporoz için risk faktörleri açısından değerlendirilmelidir. Diyabetik hastalarda sıklıkla meydana gelen bazı kırıklar diyabetin iskelet üzerindeki sistemik etkisine bağlı olmayabilir, bu hastalıkta yaygın olan hipoglisemi, nöropati, propriyosepsiyon denge kaybı ve koordinasyon kaybı da risk faktörleri açısından değerlendirilmelidir.

Etik Kurul Kararı: Bu çalışma için etik kurul onayı Dicle Üniversitesi Hayvan Deneyleri Yerel Etik Kurulu'ndan alınmıştır(01/10/2019106141).

Çıkar Çatışması Beyanı: Yazarlar çıkar çatışması olmadığını bildirmişlerdir.

Finansal Destek: Bu çalışma her hangi bir fon tarafından desteklenmemiştir.

Declaration of Conflicting Interests: The authors declare that they have no conflict of interest.

Financial Disclosure: No financial support was received. 


\section{KAYNAKLAR}

1. Uğan R, Yayla $M$, Ün $H$, et al. Nar kabuğu ekstresinin sıçanlarda diyabetik şartlarda sepsis ile indüklenen akciğer hasarına karşı etkileri. Dicle Tıp Dergisi. 2020; 47: 678-86.

2. Yan W, Li X. Impact of diabetes and its treatments on skeletal disease. Frontiers of medicine. 2013; 7: 81-90.

3. Jiao H, Xiao E. Diabetes and Its effect on bone and fracture healing. Curr Osteoporos Rep. 2015; 13: 327-335

4. Thrailkill KM, Lumpkin CK, Bunn RC, et al. Is insulin an anabolicagent in bone? Dissecting the diabetic bone forclues. American journal of physiology Endocrinology and metabolism. 2005; 289: 735-45.

5. Demir E, Yılmaz Ö. Deneysel diyabetin kas dokusunda oluşturduğu biyokimyasal değişiklikler üzerine acı badem yağının etkisi. Adıyaman Üniversitesi Fen Bilimleri Dergisi.2015; 5: 132-48.

6. Silva M, Brodt M, Lynch M, et al. Type 1 Diabetes in Young Rats Leads to Progressive Trabecular Bone Loss, Cessation of Cortical Bone Growth, and Diminished Whole Bone Strength and Fatigue Life. J Bone MinerRes. 2009; 24: 1618-27.

7. Sundararaghavan V, Mazur M, Evans $M$, et al. Diabetes and bone health: latest evidence and clinical implications. Ther Adv Musculoskelet Dis. 2017; 9: 67-74.

8. Lu H, Kraut D, Gerstenfeld L, et al. Diabetes interferes with the bone formation by affecting the expression of transcription factors that regulate osteoblast differentiation. Endocrinology. 2003; 144: 346-52.

9. Chen H, Li J, Wang Q, et al. Associations between bone-alkaline phosphatase and bone mineral density in adults with and without diabetes. Medicine (Baltimore). 2018; 97: 04-32.

10. Berridge MJ. Vitamin D deficiency and diabetes. Biochem J. 2017; 474: 1321-32.

11. Bierschenk L, Alexander J, Wasserfall C, et al. Vitamin D Levels in Subjects With and Without Type 1 Diabetes Residing in a SolarRich Environment. Diabetes Care. 2009; 32: 1977-9.

12. Wood R J, Allen L H, Bronner F, et al. Regulation of calcium metabolism in streptozotocin-induced diabetes. Am J Physio. 1984; 247: 120-3.

13. Al-Hariri M. Sweet Bones: The Pathogenesis of Bone Alteration in Diabetes. Journal of Diabetes Research. 2016; 2016: 1-5.

14. Lee $\mathrm{C}$, Lien $\mathrm{Y} H$, Lai $L$, et al. Increased renal calcium and magnesium transporter abundance in streptozotocin-induced diabetes mellitus. Kidney international. 2006; 69: 1786-91. 